\title{
The GH-IGF1 axis and longevity. The paradigm of IGF1 deficiency
}

\section{Zvi Laron}

Endocrinology and Diabetes Research Unit, Schneider Children's Medical Center of Israel, Petah Tikva, Sackler Faculty of Medicine, Tel Aviv University, Israel

\begin{abstract}
Primary or secondary IGF1 deficiency has been implicated in shortening of lifespan. This paper reviews available data on the influence of IGF1 deficiency on lifespan and longevity in animals and man. It has been shown that inactivation of the IGF1 gene or of the GH receptor in both invertebrates (C-elegans, flies-Drosphila) and rodents (mice and rats), leading to IGF1 deficiency, prolong life, particularly in females. In man, evaluation of the 2 largest cohorts of patients with Laron syndrome (inactive GH receptor resulting in IGF1 deficiency) in Israel and Ecuador revealed that despite their dwarfism and marked obesity, patients are alive at the ages of 75-78 years, with some having reached even more advanced ages. It is assumed that a major contributing factor is their protection from cancer, a major cause of death in the general population.
\end{abstract}

Key words: Aging, GH deficiency, IGF1 deficiency, Insulin, Insulin sensitivity, Lifespan, Longevity

\section{INTRODUCTION}

As the relationship between Growth Hormone Deficiency (GHD) and longevity is controversial, ${ }^{1,2}$ it is worth examining whether the paradigm of congenital IGF1 deficiency could contribute to clarification of this issue and resolve pertinent questions. Parallel with growth hormone, serum IGF1 decreases with age, reaching serum levels of $150 \mathrm{ng} / \mathrm{ml}$ at around age 50 and about $100 \mathrm{ng} / \mathrm{ml}$ at around age 80 years (Figure

Address for correspondence:

Professor Z. Laron, MD, Endocrinology and Diabetes

Research Unit, Schneider Children's Medical Center of Israel, Petah Tikva 49202, Israel, Tel. 972-3-9253610/1;

Fax 972-3-9222996; e-mail: laronz@clalit.org.il

Received 17-09-07, Revised 15-10-07, Accepted 10-11-07
1) ${ }^{3,4}$ In childhood onset GHD, the IGF1 values are lower than normal for age (Figure 1). The changes of paracrine IGF1 with advancing of age are unknown. The increase of cardiovascular disease with age is considered to be the major cause of non-traumatic death in the western world, ${ }^{5}$ shortening the normal lifespan. Cancer is another cause. ${ }^{6}$ Both types of diseases are also known to influence the lifespan in $\mathrm{GH} / \mathrm{IGF} 1$ deficient patients. Below is an overview of the known facts.

\section{WHAT IS THE EVIDENCE THAT IGF1 INFLUENCES THE LIFESPAN?}

\section{Prolonged and/or increased IGF1 secretion}

The example in man is acromegaly, which is char- 


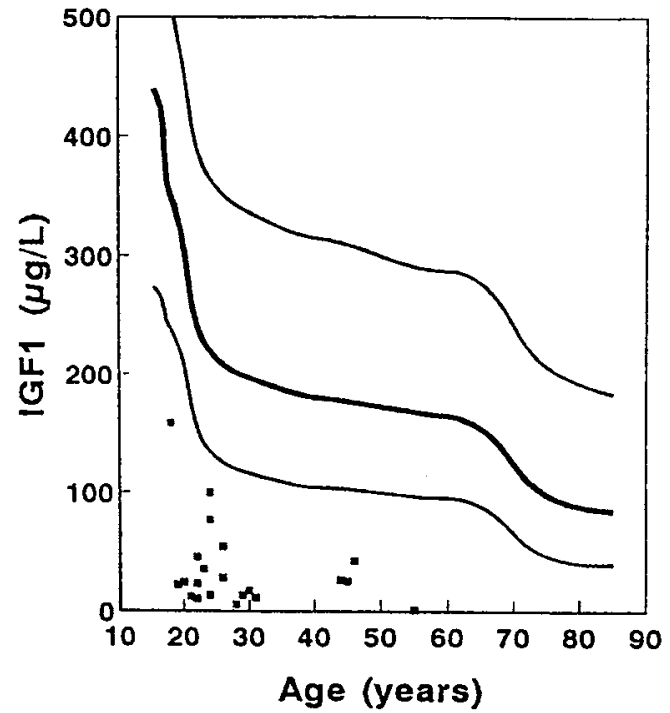

Figure 1. Decrease of serum IGF1 levels with age. Dots represent levels in patients with childhood onset GH deficiency (with permission from Blum $\mathrm{W}^{4}$ ).

acterized by increased levels of IGF1 and enhanced mortality via cardiovascular disease, diabetes and malignancy. ${ }^{7}$ The animal counterparts are GH-transgenic mice who have chronically elevated levels of $\mathrm{GH}$ in the peripheral circulation and consequently an increase in the production of IGF $1 .{ }^{8}$ These mice have an increased incidence of mammary tumors ${ }^{9}$ and hepatomas ${ }^{10}$ which contribute to the shortened lifespan of the animals. ${ }^{10}$

\section{IGF1 deficiency}

Animal models have established the IGF1 signaling pathway as a key modulator of aging and longevity in invertebrates and rodents.

\section{Invertebrates}

In the nematode "Caenorhabditis elegans", mutants of daf-2, a homolog of the insulin/IGF1 tyrosine kinase receptor, live three times longer than the wild-type animals. ${ }^{11,12}$ Binding of the insulin/IGF1 ligand to daf-2 initiates a cascade leading to daf-16, a regulatory transcription factor. During starvation, deactivation of daf- 2 and reduced daf- 16 activity, a state of arrested development (dauer formation), fat accumulation and delayed reproduction result in increased lifespan. A similar process was shown in the fly "Drosophila melanogaster". ${ }^{13}$

\section{Rodents}

Inactivation of the Igf1r gene in mice ${ }^{14}$ revealed that null mutants are not viable, while heterozygous KO mice (Igf1r + /-) lived on average $26 \%$ longer than their wild-type litter mates, with female Igf1r $+/$ - mice living longer than the male. ${ }^{14}$

\section{Inactivation of the GHRH receptor gene}

Missense mutations of the GHRH receptor gene in the lit/lit mice, which cause very low IGF1 levels, result in a prolongation of lifespan by $20-25 \% .{ }^{15}$

\section{Inactivation of the $\mathrm{GH}$ reseptor gene}

Targeted disruption of the mouse growth hormone receptor/binding protein gene (GHR/BP KO-/-, the Laron mouse $)^{16}$ resulted in dwarfism and an increased lifespan, most markedly in the female mice ${ }^{17}$ (Table 1). These mice that are similar to the human model $^{18}$ have low IGF1 and high GH levels.

\section{Humans}

At present, there is only one model with sufficient adult patients to review this issue, namely Laron syndrome (LS, primary GH insensitivity or resistance), a recessively inherited syndrome caused by deletions or mutations in the $\mathrm{GH}$ receptor or post-receptor pathways. ${ }^{18}$ Due to the clinical unavailability of IGF1, which constitutes their only treatment, it has been possible to evaluate the lifespan and morbidity in a sizeable number of untreated patients. The consequences of long-term IGF1 deficiency are: dwarfism, progressive and marked obesity, ${ }^{19}$ hyperlipidemia,${ }^{20}$ relative insulin resistance ${ }^{21}$ and even Type 2 diabetes with its vascular complications in some patients after age $40 . \cdot^{18,22}$

Table 1. Lifespan of GHR/BP gene-disrupted (Laron) mice

\begin{tabular}{lccc}
\hline Gender & Genotype & N & Life span (days) $^{*}$ \\
\hline Males & $+/+$ & 7 & $629 \pm 72$ \\
& $+/-$ & 8 & $668 \pm 51$ \\
& $-/-$ & 7 & $975 \pm 106^{\mathrm{a}}$ \\
Females & $+/+$ & 13 & $749 \pm 41$ \\
& $+/-$ & 19 & $701 \pm 36$ \\
& $-/-$ & 11 & $1031 \pm 41^{\mathrm{b}}$ \\
\hline
\end{tabular}

* Mean \pm SE

${ }^{a} \mathrm{p}<0.02$ compared to $+/+$

${ }^{\mathrm{b}} \mathrm{p}<0.005$ compared to $+/+$

Reproduced with permission from Coschigano, et al. ${ }^{17}$ 
There are two large cohorts of patients with Laron syndrome in which longevity data are available: a) the Israeli cohort numbering at present 65 patients and followed up by our group since $1958,{ }^{18}$ and b) the Ecuadorian cohort estimated at 135 patients. ${ }^{23,24}$

a) The Israeli cohort of Laron syndrome patients

Out of the 65 LS patients, some are children, a number of whom have been treated with IGF1. ${ }^{25} \mathrm{We}$ have registered 2 deaths: one girl in infancy probably due to hypoglycemia and one 78-year old male patient by road accident. The untreated adult patients whom we now monitor range in age from 25 to 60 . Almost all the patients of this cohort are of Jewish Oriental, Arab and Mediterranean origin.

\section{b) The Ecuadorian cohort (LS-E)}

Recently compiled data ${ }^{24}$ revealed 75 living patients, the oldest recorded aged 76 years. Six patients of the originally recorded cohort ${ }^{23}$ have died, five of myocardial infarction and one in an accident. The age was not specified. Twenty-two children with LS-E have died at an early age, apparently from infections and/or hypoglycemia. ${ }^{24}$ Most of the Ecuadorian patients live among or originate from isolates in the mountains in the southern region of Loja in Ecuador. ${ }^{26}$

\section{SYNOPSIS}

Several animal models definitely prove that congenital IGF1 deficiency prolongs lifespan, especially in females. ${ }^{11-17}$ These animals have, in addition to low IGF1, reduced insulin and glucose levels. ${ }^{27}$ Caloric restriction has also been proposed as playing an important role. ${ }^{28}$

In the Laron syndrome patients, ages of up to 76 and 78 have been recorded. Our patients with hypercholesterolemia are being successfully treated with statins, while the patients with Type 2 diabetes and cardiovascular disorder are now at age 55 years despite erratic diabetes control. The second patient with diabetes and complications died in a road accident. Our 56-year old female subject with glucose intolerance is currently under treatment.

Detailed data on the Ecuador cohort and patients from other countries ${ }^{18,29}$ are missing.

Despite reports of death at an early age among patients with isolated $\mathrm{GH}$ deficiency ${ }^{2}$ as well as those with hypopituitarism, ${ }^{30,31}$ untreated patients with congenital isolated IGF1 deficiency seem to reach old age despite marked obesity, development of hyperlipidemia and a tendency to develop diabetes and its complications.

The possible reasons are:

- Laron syndrome patients are protected from development of cancer; ${ }^{32}$

- They have relatively low insulin levels relative to their degree of obesity;

- The hyperlipidemia, glucose intolerance, diabetes and cardiac states are nowadays treatable.

In conclusion, lifelong IGF1 deficiency permits ageing and does not shorten lifespan, possibly even prolonging it, one major reason being that these patients are protected from cancer, a major cause of death in the general population.

\section{Epilogue}

There is an isolated village called Vilcabamba situated in the mountains about $40 \mathrm{~km}$ from the city of Loja in Ecuador which has long been renowned for the remarkable longevity of its inhabitants, who attain lifespans of 85 and up to and even over 100 years. ${ }^{33}$ We are at present carrying out research as to whether there is any genetic link between these long-living people and the Laron syndrome patients in Loja.

\section{REFERENCES}

1. Laron Z, 2005 Do deficiencies in growth hormone and insulin-like growth factor-1 (IGF-1) shorten or prolong longevity? Mech Ageing Dev 126: 305-307.

2. Besson A, Salemi S, Gallati S, et al, 2003 Reduced longevity in untreated patients with isolated growth hormone deficiency. J Clin Endocinol Metab 88: 3664-3667.

3. Silbergeld A, Litwin A, Bruchis S, Varsano I, Laron Z, 1986 Insulin like growth factor I (IGF1) in healthy children, adolescents and adults as determined by a radioimmunoassay specific for the synthetic 53-70 peptide region. Clin Endocrinol 25: 67-74.

4. Blum WF 2000 Insulin-like growth factors (IGF) and IGF-binding proteins: their use for diagnosis of growth hormone deficiency. In:Juul Jorgensen JOL (eds) Growth 
hormone in adults, Cambridge University Press Cambridge; pp. 54-86.

5. Jneid H, Bhatt DL, 2003 Advances in antiplatelet therapy. Expert Opin Emerg Drugs 8: 349-363.

6. Calle EE, Rodriguez C, Walker-Thurmond K, Thun MJ, 2003 Overweight, obesity and mortality from cancer in a prospectively studied cohort of US adults. N Engl J Med 348: 1625-1638.

7. Orme S, McNally RJQ, Cartwright RA, Belchetz PE, 1998 Mortality and cancer incidence in acromegaly: a retrospective cohort study. J Clin Endocrinol Metab 83: 2730-2734.

8. Sotelo AI, Bartke A, Turyn D, 1993 Effects of bovine growth hormone $(\mathrm{GH})$ expression in transgenic mice on serum and pituitary immunoreactive mouse GH levels and pituitary GH-releasing factor binding sites. Acta Endocrinol 129: 446-452.

9. Cecim M, Bartke A, Yun JS, Wagner TE, 1994 Expression of human, but not bovine growth hormone genes promotes development of mammary tumors in transgenic mice. Transgenics 1: 431-437.

10. Bartke A, 2003 Can growth hormone $(\mathrm{GH})$ accelerate aging? Evidence from GH-transgenic mice. Neuroendocrinology 78: 210-216.

11. Kimura KD, Tissenbaum HA, Liu Y, RuvkunG, 1997 daf-2 an insulin receptor-like gene that regulates longevity and diapause in Caenorhabditis elegans. Science 277: 942-946.

12. Murphy CT, McCarroll SA, Bargmann CI, et al, 2003 Genes that act downstream of DAF-16 to influence the lifespan of Caenorhabditis elegans. Nature 424: 277283.

13. Clancy DJ, Gems D, Harshman LG, et al, 2001 Extension of life span by loss of CHICO, a Drosophila insulin receptor substrate protein. Science 292: 104-106.

14. Holzenberger M, Dupont J, Ducos B, et al, 2003 IGF1 receptor regulates lifespan and resistance to oxidative stress in mice. Nature 421: 182-187.

15. Flurkey K, Papaconstantinou J, Miller RA, Harrison DE, 2001 Lifespan extension and delayed immune and collagen aging in mutant mice with defects in growth hormone production. Proc Natl Acad Sci USA 98: 6736-6741.

16. Zhou Y, Xu BC, Maheshwari HG, et al, 1997 A mammalian model for Laron syndrome produced by targeted disruption of the mouse growth hormone receptor binding protein gene (the Laron mouse). Proc Natl Acad Sci USA 94: 13215-13220.

17. Coschigano KT, Clemmons D, Bellush LL, Kopchick JJ, 2000 Assessment of growth parameters and life span of GHR/BP gene disrupted mice. Endocrinology 141: 2608-2613.

18. Laron Z, 2004 Laron syndrome (Primary growth hormone resistance or insensitivity): The personal experience 1958-2003. J Clin Endocrinol Metab 89: 1031-1044.

19. Laron Z, Ginsberg S, Lilos P, Arbiv M, Vaisman N, 2006 Body composition in untreated adult patients with Laron syndrome (primary GH insensitivity). Clin Endocrinol 65: 114-117.

20. Laron Z, Klinger B, 1993 Body fat in Laron syndrome patients:effect of insulin like growth factor I treatment. Hormone Res 40: 16-22.

21. Laron Z, Avitzur Y, Klinger B, 1995 Carbohydrate metabolism in primary growth hormone resistance (Laron syndrome) before and during insulin like growth factor I treatment. Metabolism 44: 113-118.

22. Laron Z, Weinberger D, 2004 Diabetic retinopathy in two patients with congenital IGF1 deficiency (Laron syndrome). Europ J Endocrinol 151: 103-106.

23. Rosenbloom AL, Guevara-Aguirre J, Rosenfeld RG, Francke U, 1999 Growth hormone receptor deficiency in Ecuador. J Clin Endocrinol Metab 84: 4436-4443.

24. Guevara-Aguirre J, Guevara-Aguirre M, Saavedra J, Bernstein G, 2007 Low serum levels of IGF-1, BP3 and ALS are associated to severe short stature, obesity, premature aging, increased cardiovascular mortality and absence of cancer in the Ecuadorian cohort of Laron syndrome subjects. Horm Res 68: 175.

25. Laron Z, Ginsberg S, Lilos P, Arbiv M, Vaisman N, 2006 Long term IGF1 treatment of children with Laron syndrome increases adiposity. Growth Horm IGF Res 16: 61-64.

26. Rosenbloom AL, Guevara-Aguirre J, Rosenfeld RG, Fielder PJ, 1990 The little women of Loja - growth hormone receptor deficiency in an inbred population of Southern Ecuador. N Engl J Med 323: 1367-1374.

27. Tatar M, Bartke A, Antebi A, 2003 The endocrine regulation of aging by insulin like signals. Science 299 : 1346-1351.

28. Al-Regaiey KA, Masternak MM, Bonkowski M, Sun L, Bartke A, 2005 Long lived growth hormone receptor knockout mice: interaction of reduced insulin like growth factor I/insulin signaling and caloric restriction. Endocrinology 146: 851-860.

29. Shevah O, Rubinstein M, Laron Z, 2004 Molecular defects of the growth hormone receptor gene, including a new mutation, in Laron syndrome patients in Israel: relationship between defects and ethnic groups. Isr Med Assoc J 6: 630-633.

30. Rosen T, Bengtsson BA, 1990 Premature mortality due to cardiovascular disease in hypopituitarism. Lancet 336 : 285-288.

31. Tomlison JW, Holden N, Hills RK, et al, 2001 Association between premature mortality and hypopituitarism. Lancet 357: 425-431.

32. Shevah O, Laron Z, 2007 Patients with congenital deficiency of IGF1 seem protected from the development of malignancies: a preliminary report Growth Horm IGF Res 17: 54-57.

33. Christiensen K, Vaupel JW, 1996 Determinants of longevity: genetic, environmental and medical factors. J Int Med 240: 333-341. 